\title{
A novel anticancer agent SNG1153 inhibits growth of lung cancer stem/progenitor cells
}

\author{
Shiyang Liu', ${ }^{1,}$, Yuming Guo ${ }^{2, *}$, Jing Wang ${ }^{2}$, Hai Zhu², Yuqing Han², Mingji Jin², Jun \\ Wang $^{2}$, Congya Zhou ${ }^{2}$, Junfeng Ma', Qingcong Lin'², Zhaoyi Wang ${ }^{2}$, Kun Meng ${ }^{2}$, \\ Xueqi Fu ${ }^{1}$ \\ ${ }^{1}$ School of Life Sciences, Jilin University, Changchun, P.R. China \\ ${ }^{2}$ Beijing Shenogen Biomedical Co., Ltd, Beijing, P.R. China \\ *These authors contributed equally to this work
}

Correspondence to: Kun Meng, email: kun.meng@shenogen.com Xueqi Fu, email: fuxueqi0702@163.com

Keywords: SNG1153, lung cancer, CSC, tumorsphere, $\beta$-catenin

Received: December 01, 2015

Accepted: May 20, 2016

Published: June 02, 2016

\begin{abstract}
Lung cancer is the leading cause of cancer-related death in both men and women. Lung cancer contains a small population of cancer cells with stem-like features known as cancer stem cells (CSCs). CSCs are often more resistant to current therapeutic treatments. Thus, it is urgent to develop a novel agent that is able to inhibit CSCs growth. In this study, we examined the ability of SNG1153, a novel chemical agent to inhibit the growth of lung CSCs. We found that SNG1153 inhibited growth and induced apoptosis in established lung cancer cells. We also found that SNG1153 inhibited the tumorsphere formation and decreased CD133-positive (lung CSC marker) cancer cells. SNG1153 was able to attenuate tumor formation in NOD/SCID (non-obese diabetic/ severe combined immunodeficient) mice injected with lung tumorsphere cells. We further demonstrated that SNG1153 induced $\beta$-catenin phosphorylation and downregulated $\beta$-catenin. Our results thus demonstrate that SNG1153 effectively inhibits the growth of lung CSCs and suggest that SNG1153 may be a novel therapeutic agent to treat human lung cancer.
\end{abstract}

\section{INTRODUCTION}

Human lung cancer is the most common cause of cancer-related mortality in the world and affects more than one million people yearly $[1,2]$. Despite the continuous efforts to improve the therapeutic response, the overall five-year survival rate is still very low [1].

Recently, it has been demonstrated that a subpopulation of cancer cells harboring stem cell features known as cancer stem cells sustain the growth of tumors and are often resistant to the current cancer therapies. CSCs are a small subpopulation of undifferentiated cells within tumors that are responsible for tumor initiation, maintenance, and metastasis [3-5]. CSCs have been identified in various human tumors, such as breast, brain, prostate, pancreatic, colon and lung cancers [1, 3, 6-11]. CSCs-enriched cancer cell populations form tumorsphere in low-adherence culture in vitro $[12,13]$ and exhibit the ability to form tumors at limiting dilutions in vivo [1]. Distinct markers have been identified for purification of cancer stem cells, such as CD133, CD $44^{\text {high }} / \mathrm{CD} 24^{\text {low }}$, ABCG2, ALDH-1 [1, 6, 7, 9, 11, 14-17].

The current cancer therapies usually lack efficacy in long-term outcome because they fail to target CSCs [18]. Thus, developing new therapeutics targeting CSCs is opening up a new avenue for drug discovery $[19,20]$. Aberrant stem cell signaling pathways (such as WNT, FGF, Notch, Hedgehog, and TGF/BMP and so on) result in the transformation of normal stem cells to cancer stem cells, and induce various diseases, including cancer, fibrosis and degenerative diseases [21-27]. Among them, WNT is one of the most important signaling pathways in the drug discovery field over the past decade and has been reported to maintain CSCs of myeloid leukemia, melanoma, breast, 
colon, liver, and lung cancers [17, 28]. The most advanced clinical compound, salinomycin was reported to inhibit mammary tumor growth in vivo and induce increased epithelial differentiation of tumor cells [29]. A subsequent study has demonstrated that salinomycin exerts anti-CSC effects by inhibiting WNT signaling cascade through interfering with LPR6 phosphorylation [30]. Here we show that SNG1153 induces $\beta$-catenin phosphorylation and then down-regulates $\beta$-catenin, a crucial component of the WNT pathway, which plays a key role in cancer stem cells.

SNG1153 is a synthetic compound derived from icaritin which is purified from Epimedium Genus, a traditional Chinese herbal medicine. Icaritin exhibits multiple biological activities, such as cardiovascular function improvement, hormone regulation, modulation of immunological function and antitumor activity [31-38].

In this study, we investigated the effects of SNG1153 on the growth of the stem/progenitor cells derived from lung cancer $\mathrm{H} 460$ cells.

\section{RESULTS}

\section{SNG1153 exhibits growth inhibitory activity in lung cancer cells}

SNG1153 is a derivate of icaritin, a hydrolytic product of icariin from Epimedium (Figure 1A). Icaritin has many pharmacological and biological activities, such as the treatment of liver cancer, breast cancer and other diseases [31-38]. To evaluate the effects of SNG1153 on the growth of lung cancer cells, CCK8 assay was performed in the established lung cancer $\mathrm{H} 460$ cells treated with various concentrations of SNG1153 for $48 \mathrm{~h}$. We found that SNG1153 effectively inhibited the growth of H460 cells in a dose-dependent manner (Figure 1B). Taxol and salinomycin were used as controls (Figure S1A, S1B). Additionally, SNG1153 inhibited the colony forming activity of H460 cells in a dosedependent fashion (Figure 1C, 1D). These data suggested that SNG1153 exerts potent inhibitory effects on lung cancer cell growth in vitro. SNG1153 exhibits a better bioavailability after orally administration and the $\mathrm{IC}_{50}$ of SNG1153 is only one sixth of icaritin in H460 cells (Figure S2). These results indicated SNG1153 has better bioavailability and safety than icaritin.

During the experiments, we noticed that there were floating cells when H460 cells treated with SNG1153. We then decided to determine whether SNG1153 induced cell apoptosis. H460 cells were treated with different concentrations of SNG1153 for $48 \mathrm{~h}$, stained with Annexin $\mathrm{V}$ and PI and analyzed with flow cytometry to examine the early stage apoptotic cells (annexin $\mathrm{V}^{+} / \mathrm{PI}^{-}$), the late stage apoptosis cells or necrotic cells $\left(\right.$ annexin $\left.V^{+} / \mathrm{PI}^{+}\right)$, and cell debris (annexin $\left.\mathrm{V}^{-} / \mathrm{PI}^{+}\right)$. We found that $\mathrm{SNG} 1153$ indeed induced apoptosis in H460 cells (Figure 1E, 1F).

\section{SNG1153 inhibits the growth of tumorsphere cells derived from lung cancer $\mathrm{H} 460$ cells}

As cancer stem/progenitor cells are refractory to most chemotherapy agents $[4,39,40]$, we next decided to examine whether SNG1153 affects growth of lung CSCs. It has been reported that tumorspheres are capable of yielding secondary tumorspheres and differentiating along multiple lineages [12]. Our results demonstrated H460 cells in tumorsphere culture medium for 7 days were able to form tumorspheres (Figure 2A, 2B).

$\mathrm{CD} 133$ has been identified as a stem-like cell marker and used to enrich H460 lung cancer stem cells [1, 41, 42]. We examined the population of cells with CD133 positive phenotype in tumorsphere cells derived from H460 cells and found that $\mathrm{CD} 133$ positive cell population was 15-fold higher in H460 tumorsphere compared to H460 adherent cells (Figure 2C, 2D). We further found that as low as $1 \times 10^{2}$ tumorsphere cells were capable of forming tumors in NOD/SCID mice while it required $1 \times 10^{4}$ H460 adherent cells to form tumors in NOD/SCID mice (Figure 2E). These results indicated that tumorspheres highly enrich cancer stem/progenitor cells.

To examine the effect of SNG1153 on tumorsphere formation in vitro, we exposed tumorsphere cells derived from H460 cells to different concentrations of SNG1153 for 5 days and then cultured one additional passage in the absence of SNG1153. The chemotherapy agent taxol and anti-CSCs agent salinomycin were also included [29, 43]. Our data showed that both SNG1153 and salinomycin decreased the size of tumorspheres compared to vehicle controls. In contrast, taxol increased tumorsphere size significantly (Figure 3A). We next sought to examine the effects of SNG1153 on CSC self-renewal ability. The first generation tumorspheres were dissociated and passed for the second generation of tumorspheres. Both salinomycin and SNG1153 suppressed the self-renewal of lung cancer stem cells derived from $\mathrm{H} 460$ cells while the vehicle and taxol had no effect (Figure 3A).

Furthermore, SNG1153 decreased the CD133 positive population of $\mathrm{H} 460$ tumorsphere with a dosedependent manner. In contrast, taxol treatment increased the CD133 positive cell population by 2-fold (Figure 3B, 3C).

It has been reported that stemness genes such as Oct4 (octamer-binding transcription factor 4)/Nanog promote lung tumor malignancy and metastasis, by inducing cancer stem cell-like properties [44]. We further investigated the effect of SNG1153 on the Oct4/Nanog expression. We found that SNG1153 treatment significantly reduced the gene expression of the Oct4/Nanog in tumorsphere cells (Figure 3D). These results indicated that SNG1153 inhibits the growth of tumorsphere cells derived from lung cancer H460 cells. 
A<smiles>CCOc1ccc(-c2oc3c(CCC=C(C)C)c(O)cc(O)c3c(=O)c2O)cc1</smiles>

Icaritin

B

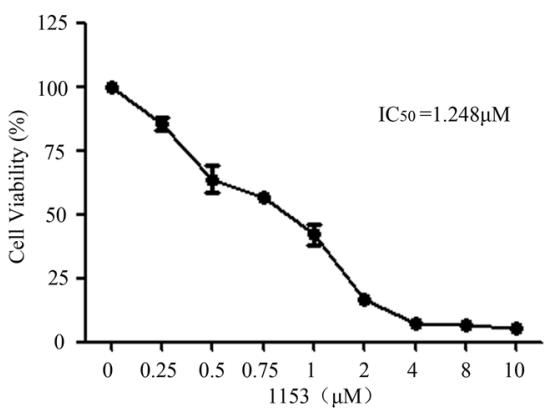<smiles>CC(C)=CCc1c(O)cc(O)c2c(=O)c(O)c(-c3ccc(C(F)(F)F)cc3)oc12</smiles>

SNG-1153

C

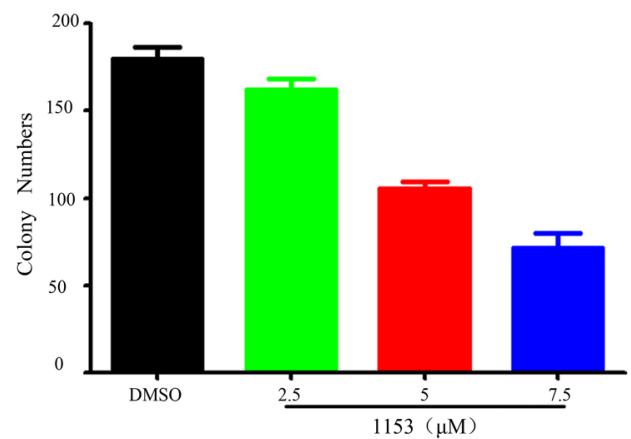

D

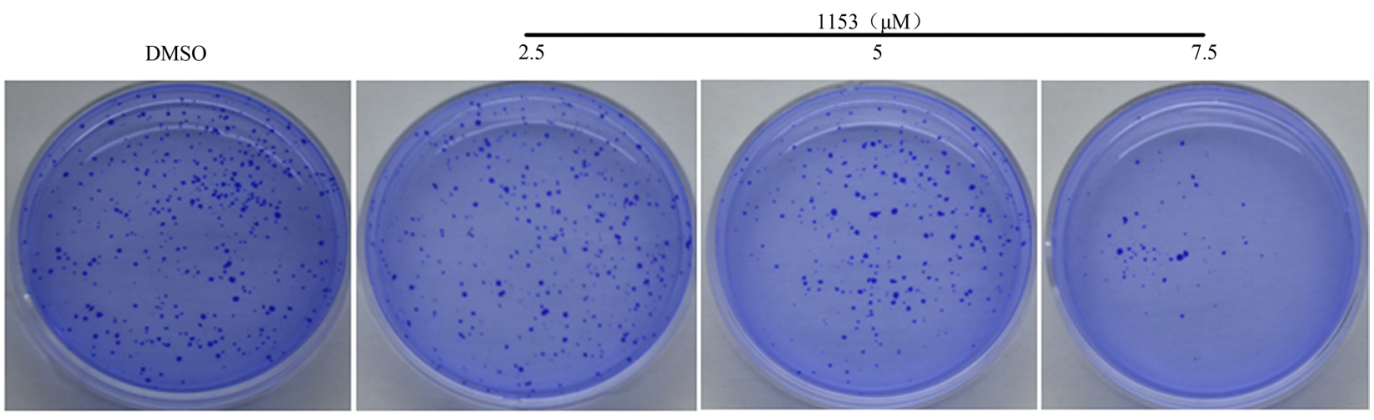

E
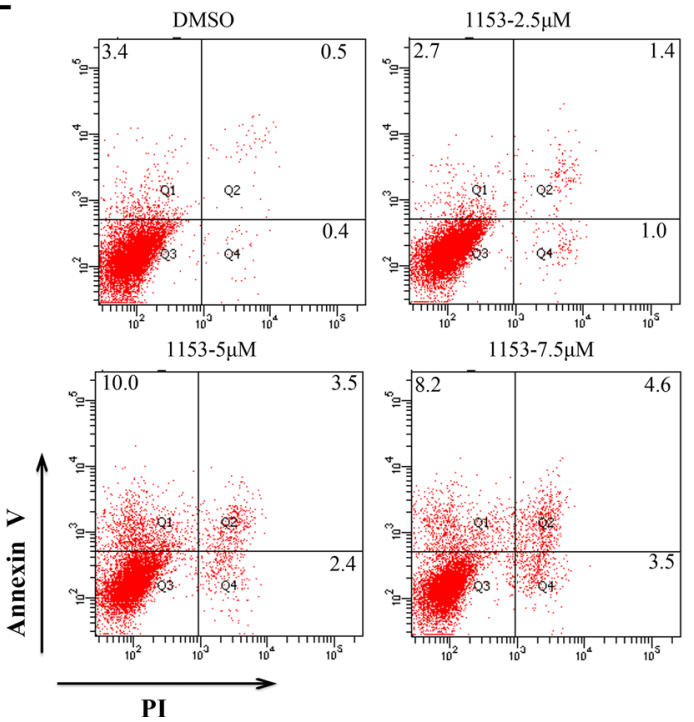

F

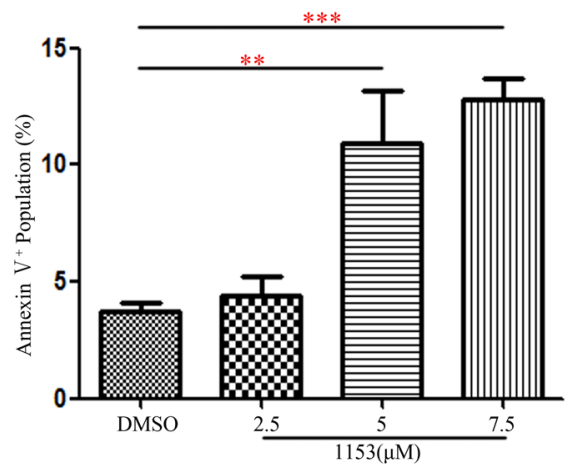

Figure1: SNG1153 inhibits growth and induces apoptosis in $\mathbf{H 4 6 0}$ lung cancer cells. (A) Chemical structure of icaritin and SNG1153. (B) SNG1153 inhibited H460 cell growth. H460 cells were treated with the indicated concentrations of SNG1153 for $48 \mathrm{~h}$ and cell growth was measured by the CCK8 assay. Point, mean $(n=3)$; bars, SD. (C and $\mathbf{D})$ Clonogenic assay of H460 cells treated with SNG1153. The cells were pretreated with SNG1153 or DMSO for $24 \mathrm{~h}$ then seeded in medium containing $0.3 \%$ soft agar in the upper layer and $0.6 \%$ soft agar in the lower layer. After 10 days, the cell colonies were counted under a microscope (E and $\mathbf{F})$ SNG1153 induced cell apoptosis. H460 cells were treated with the indicated concentrations of SNG1153 for $48 \mathrm{~h}$ and collected for apoptosis assay. The results represent three independent experiments. Points, mean $(n=3)$; bars, SEM. 1153: SNG1153. 


\section{SNG1153 reduces the tumor formation ability of tumorsphere cells in vivo}

We next want to assess the in vivo tumor-seeding ability of tumorsphere cells treated with SNG1153. We observed that SNG1153 pretreatment resulted in a reduction of the ability of tumorsphere cells to form tumors in vivo. The sites inoculated with $5 \times 10^{2}$ cells survived from SNG1153 pretreatment failed to form tumors while the vehicle and taxol pretreatment had no effect (Figure 4A, Table S1). The same results were obtained in the $5 \times 10^{4}$ groups (Figure 4B). Taken together, these results indicated that SNG1153 effectively inhibits the growth of lung cancer stem/progenitor cells.

A
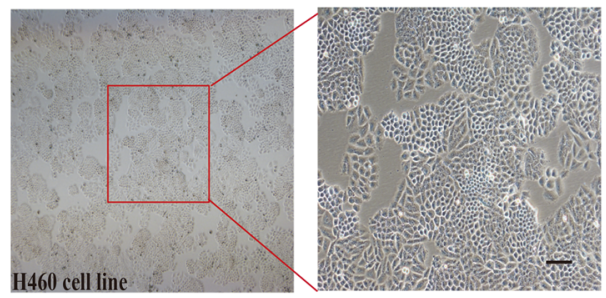

C
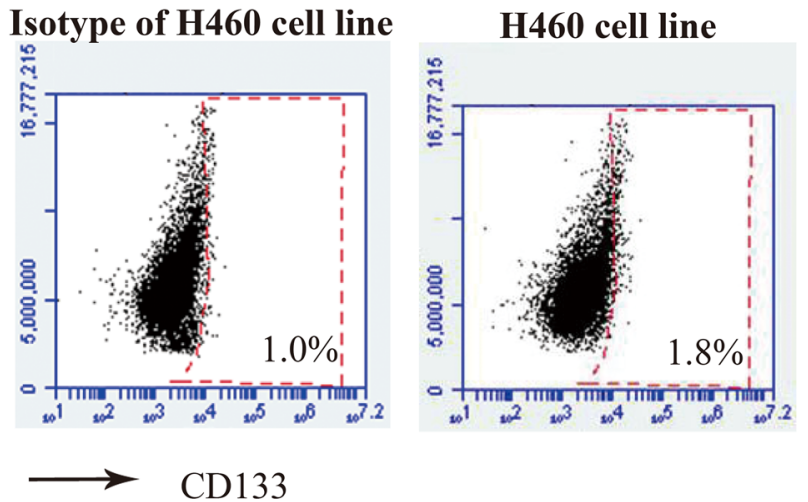

D

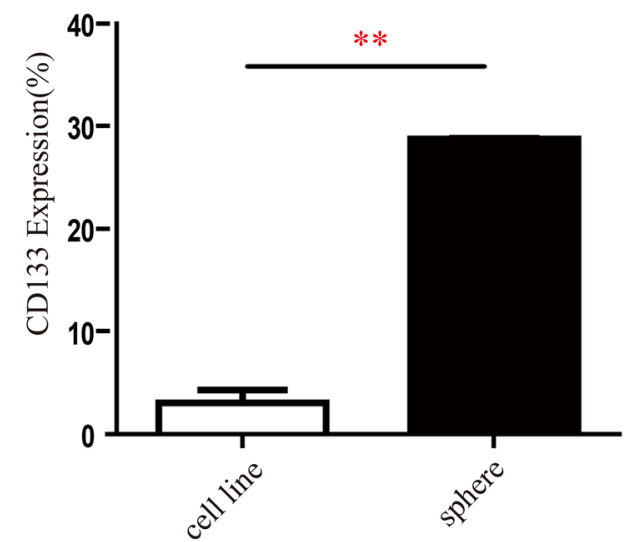

\section{SNG1153 suppresses $\beta$-catenin protein level in tumorsphere cells}

In the absence of Wnt ligand, $\beta$-catenin is phosphorylated at residues Ser45, Thr41, Ser37, and Ser33 by GSK $3 \beta$, ubiquitinated by the E3 ligase $\beta$-TrCP and degraded through the $26 \mathrm{~S}$ proteasome system. Wnt stimulation leads to the inhibition of $\beta$-catenin phosphorylation and degradation, and then $\beta$-catenin will translocate and accumulate in the nucleus where it activates the expression of the target genes, such as c-myc and CyclinD1 [28, 45, 46]. We found SNG1153 significantly reduced $\beta$-catenin protein level in a time and dose-dependent manner (Figure 5A, 5B), which

B
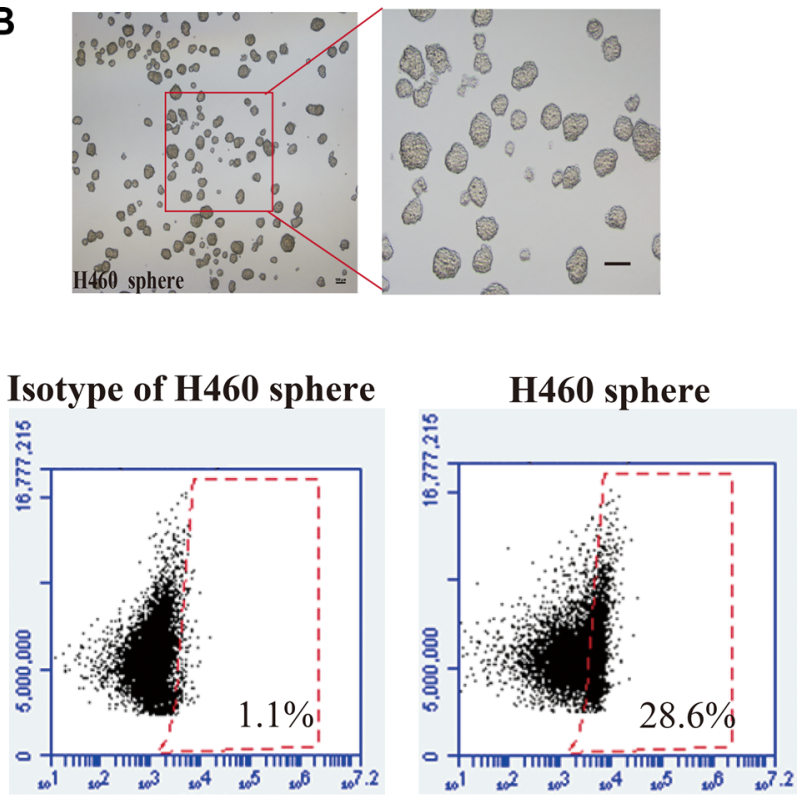

$\mathbf{E}$

\begin{tabular}{|c|c|c|}
\hline \multicolumn{3}{|c|}{ Tumor seeding } \\
\hline Cells injected & H460 cell line & H460 sphere \\
\hline $1 \times 10^{2}$ & $0 / 5$ & $5 / 5$ \\
$1 \times 10^{3}$ & $0 / 5$ & $5 / 5$ \\
$1 \times 10^{4}$ & $3 / 5$ & $5 / 5$ \\
$1 \times 10^{5}$ & $5 / 5$ & $5 / 5$ \\
$1 \times 10^{6}$ & $5 / 5$ & $5 / 5$ \\
$1 \times 10^{7}$ & $5 / 5$ & $5 / 5$ \\
\hline
\end{tabular}

Figure 2: Tumorsphere formation enriches cancer stem-like cells from $\mathbf{H 4 6 0}$ cells. (A and B) Morphology of H460 cells and tumorspheres from lung cancer H460 cells Scale bar $100 \mu \mathrm{m}$. (C and D) CD133 positive populations in H460 adherent cells and tumorsphere cells were compared. H460 cells were cultured for 5 days in tumorsphere medium or cultured for 2 days in 10\% FBS-1640 medium, subsequently the 7-AAD negative cells (living cells) were stained with anti-CD133 antibody and analyzed with flow cytometry. Points, mean $(n=3)$; bars, SEM. $(* * P<0.01)$; (E) Tumor formation in NOD/SCID mice xenografted with different number of H460 adherent cells or H460 tumorsphere cells. 


\section{B}
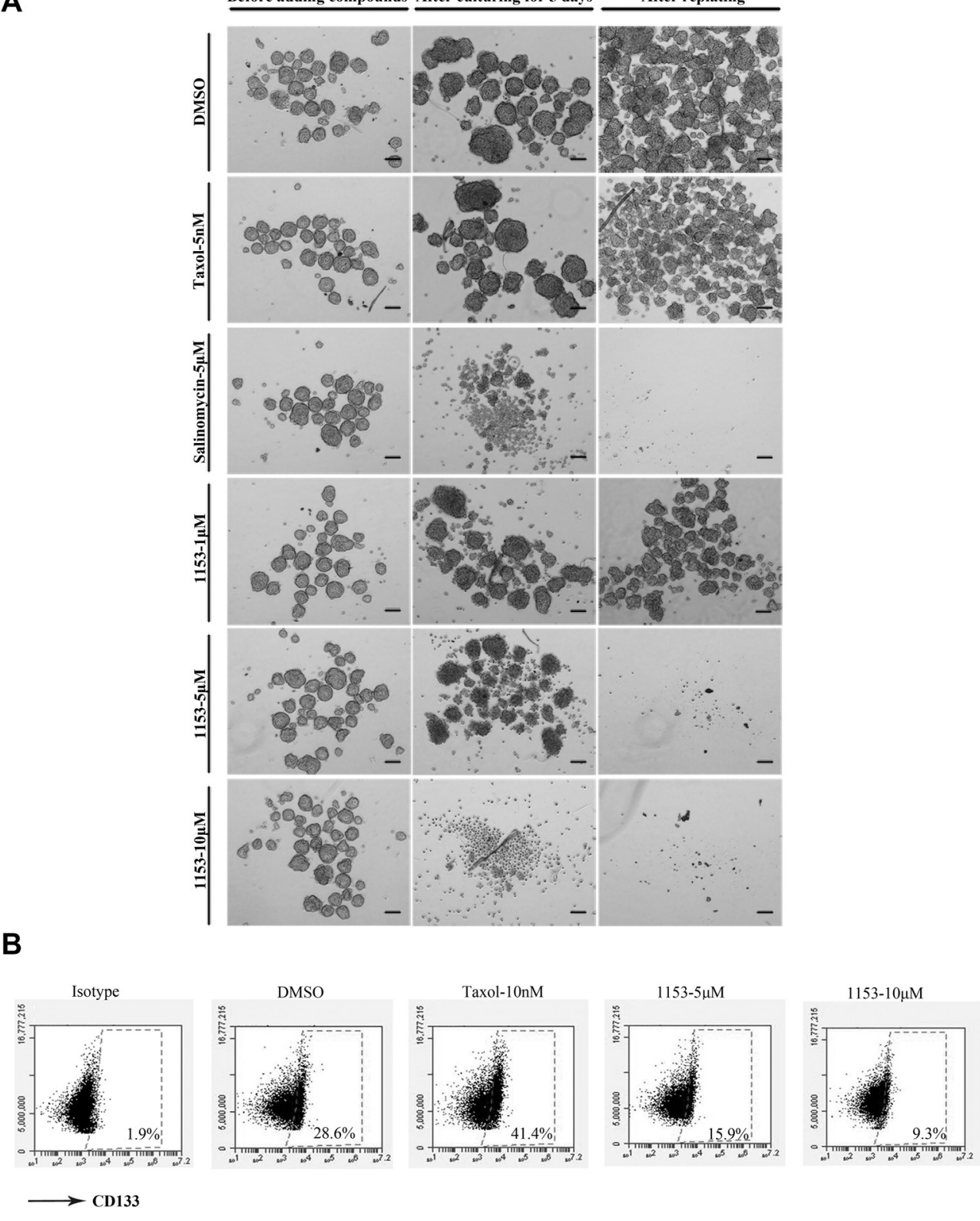

C

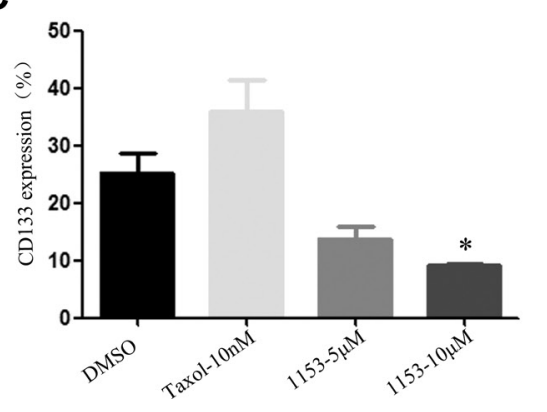

D

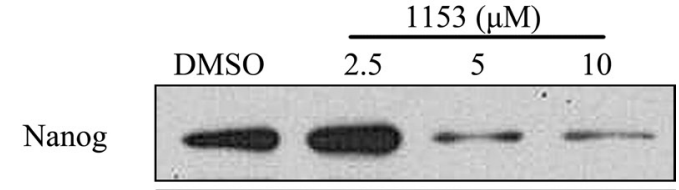

Oct-4

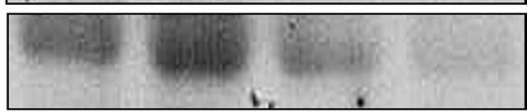

$\beta$-actin

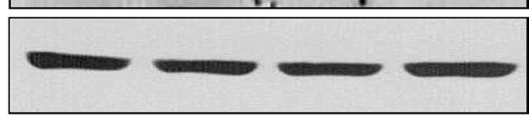

Figure 3: SNG1153 inhibits growth of $\mathbf{H 4 6 0}$ tumorsphere. (A) H460 tumorsphere cells were treated with the indicated concentrations of SNG1153 for 5 days. Taxol was used as a negative control and salinomycin as a positive control. After 5 days, tumospheres were photographed and re-seeded for second generation of tumorsphere in the absence of compounds for another 5 days to measure the selfrenewal ability. Scale bar $100 \mu \mathrm{m}$. (B and C) H460 tumorsphere cells were treated with the indicated concentrations of DMSO, SNG1153 or Taxol for 5 days and then the 7-AAD negative cells were analyzed with flow cytometric analysis after anti-CD133 antibody staining. Points, mean $(n=3)$; bars, SEM. ( ${ }^{*}<0.05$ versus Control group). (D) Western blot analysis of Nanog and Oct-4 expression in H460 tumorsphere cells treated with SNG1153. All data are representative results from three independent experiments. 1153:SNG1153. 
was reversed by MG132, a proteasome inhibitor (Figure 5C). RT-PCR assay confirmed that $\beta$-catenin mRNA level was unchanged in the presence of SNG1153 (Figure 5D). Further investigation by nucleocytoplasmic separation assay showed that SNG1153 reduced $\beta$-catenin protein level in tumorsphere cells both in the nucleus and the cytoplasm (Figure 5E). We also found SNG1153 increased GSK $3 \beta$ expression and induced the $\beta$-catenin phosphorylation (Figure $5 \mathrm{~F}$ ). Our results indicated that SNG1153 destabilizes $\beta$-catenin protein, and reduces the protein levels of $\beta$-catenin presumably through induction of GSK3 $\beta$ expression. As SNG1153 is a synthetic compound derived from icaritin, we next want to study whether they choose different signaling pathways for cancer therapy. Unlike SNG1153, icaritin did not decrease the protein levels of $\beta$-catenin, however, SNG153 suppressed Stat3 phosphorylation as icaritin did (Figure S3). These results explained why SNG1153 exerts more potent anticancer activity than icaritin in vitro.

To test the effect of SNG1153 on the expression of $\beta$-catenin downstream genes, we examined the expression of c-myc and cyclinD1 in H460 tumorspheres treated with SNG1153. We found that SNG1153 down regulated c-myc and cyclinD1 expression in a dose-dependent manner (Figure 5G).

\section{$\beta$-catenin plays a critical role for tumorsphere formation}

To further study the importance of $\beta$-catenin in lung cancer stem cells, we used siRNA specific for $\beta$-catenin to knock down $\beta$-catenin in $\mathrm{H} 460$ cells. We found that $\beta$-catenin knock down in $\mathrm{H} 460$ cells reduced tumorsphere formation (Figure 6A-6C). Thus, $\beta$-catenin plays an important role in stemness of tumorsphere cells derived from $\mathrm{H} 460$ cells.

\section{SNG1153 suppresses lung CSC via $\beta$-catenin pathway}

We next over expressed constitutively active $\beta$-catenin in $\mathrm{H} 460$ cells to further study whether SNG1153 inhibits lung CSC via $\beta$-catenin pathway. Western blot analysis showed that the constitutively active $\beta$-catenin $(\beta$-catenin-C) increased the expression levels of $\beta$-catenin (Figure 6D). Forced expression of $\beta$-catenin reduced SNG1153-inhibitory activity in tumorsphere formation (Figure 6E).

\section{DISCUSSION}

SNG1153 is a derivate from icaritin, a hydrolytic product of icariin from traditional Chinese herbal medicine Epimedium. The marked difference between SNG1153 and icaritin is that the methyl group at $\mathrm{C}^{-4}$ ' in icaritin is replaced by trifluoromethyl. Previous studies showed that icaritin inhibits breast, leukemia, endometrial and liver cancer cell growth [34-38]. Here, we examined the effect of SNG1153 on growth of lung cancer H460 cells. Our data showed SNG1153 has better bioavailability and inhibitory activity than icaritin.
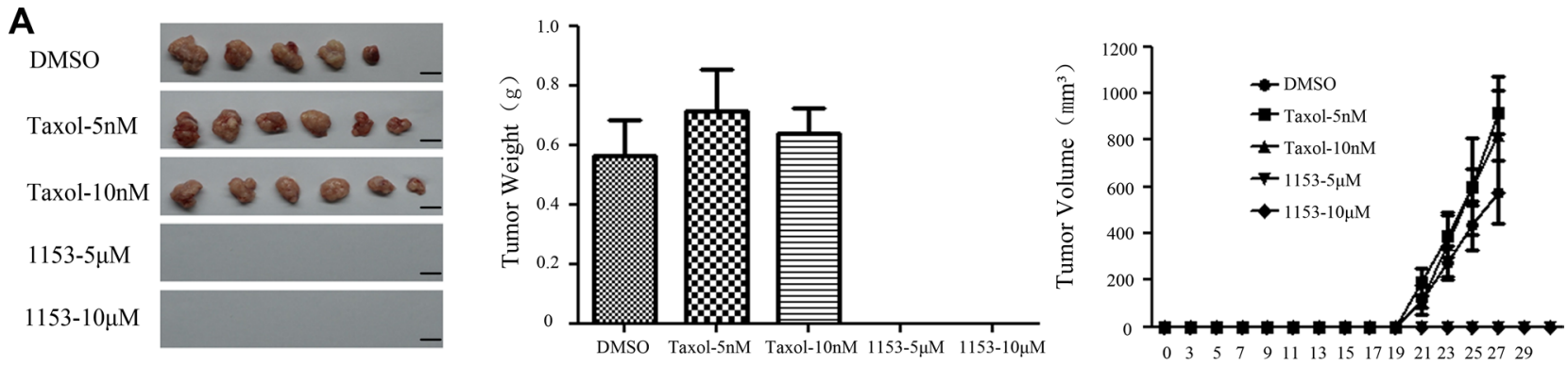

B
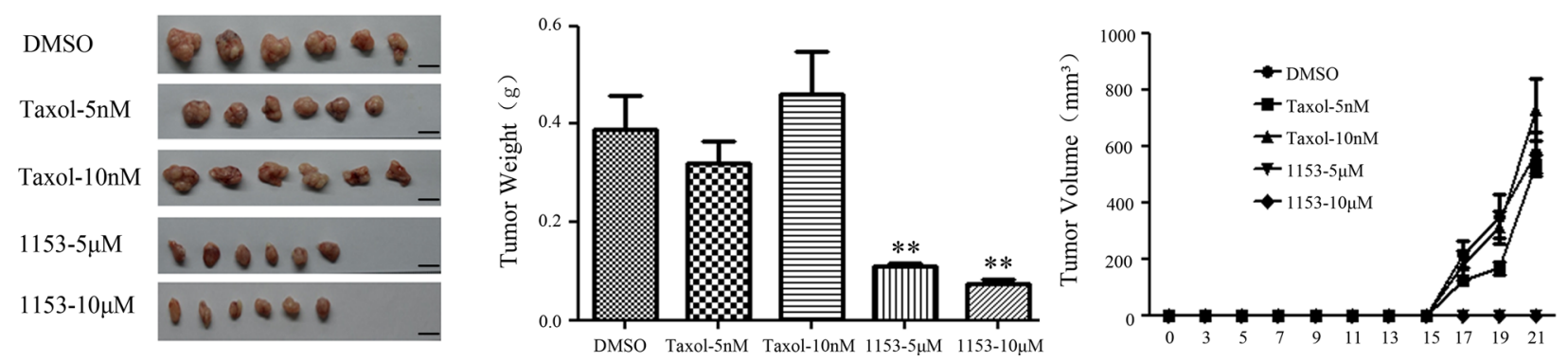

Figure 4: SNG1153 attenuates tumor formation of H460 tumorsphere cells in vivo. H460 tumorsphere cells treated with SNG1153 or Taxol for 2 days were inoculated in NOD/SCID mice. $5 \times 10^{2}$ (A) or $5 \times 10^{4}(\mathbf{B})$ of 7-AAD negative cells was used. Tumor volume weights were measured every other day for one month. Scale bar $1 \mathrm{~cm}$. Points, mean $(n=6)$, bars, SEM. $(* * P<0.01$ versus Control group). 1153: SNG1153. 
Increasing pieces of evidence indicated that human cancers are driven and sustained by a small population of cells called cancer stem cells [3]. Currently, there are few effective compounds that are targeting cancer stem cells

\section{A}

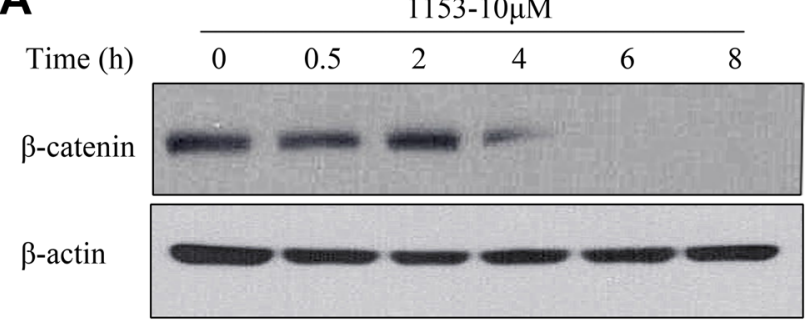

C

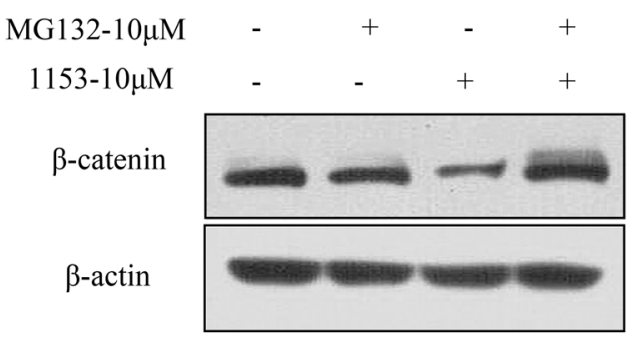

E

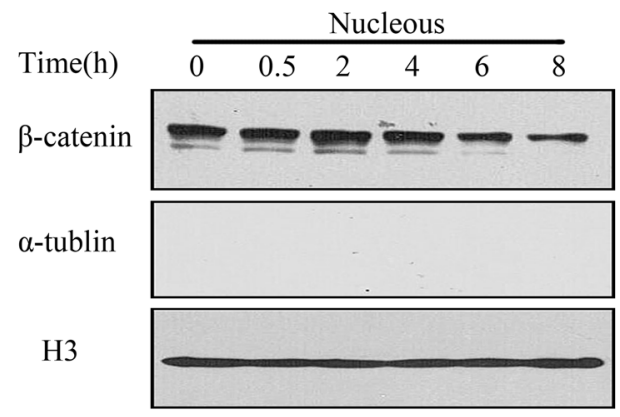

F

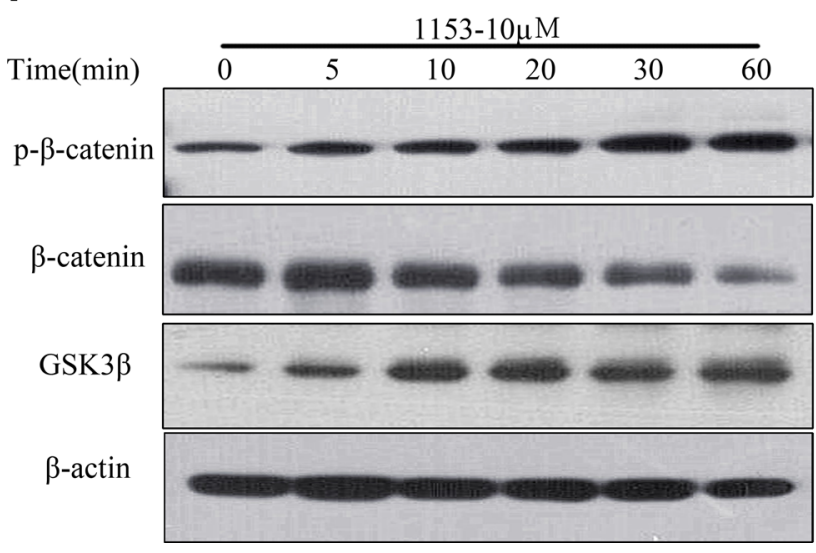

[3, 47, 48]. Many efforts have been concentrated to the identification and characterization of specific inhibitors of CSC homeostasis [49-53]. Curcumin [54, 55] and sulforaphane [56] were reported to inhibit CSC growth.
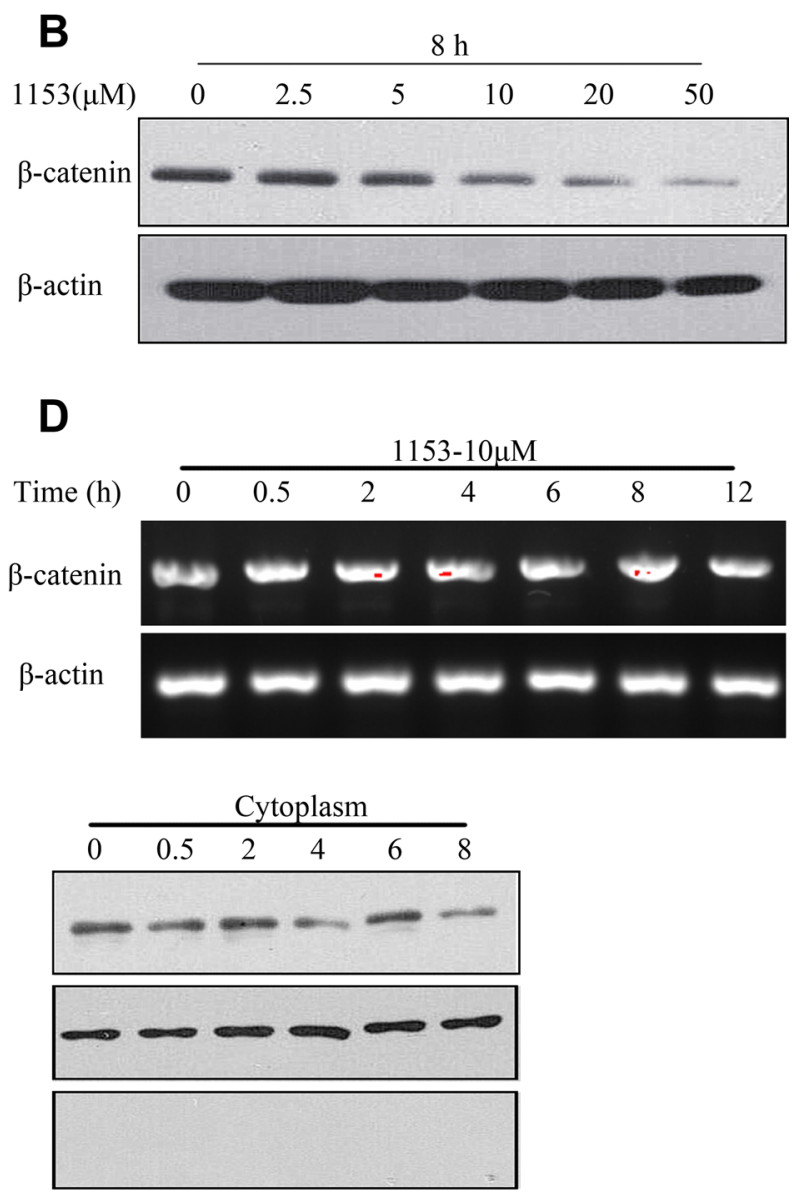

G

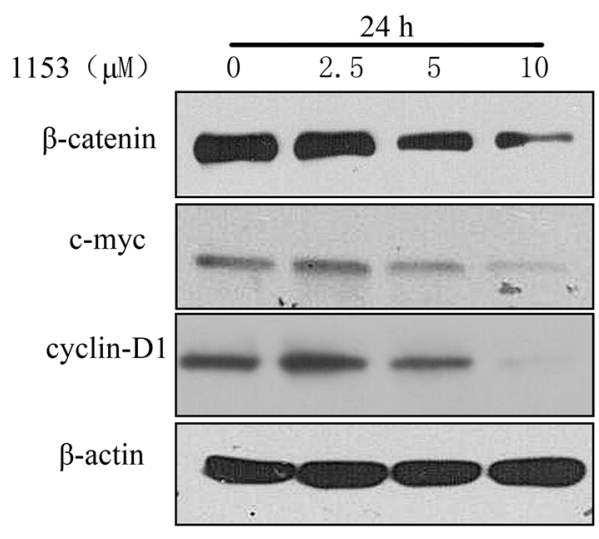

Figure 5: SNG1153 down regulates $\boldsymbol{\beta}$-catenin protein level. Western blot analysis of the $\beta$-catenin expression in $\mathrm{H} 460$ tumorsphere cells treated with SNG1153 under the different concentrations of (A) or different time periods (B). (C) Western blot analysis of $\beta$-catenin protein level in H460 tumorsphere cells treated with the proteasome inhibitor MG132 and SNG1153 for 2 h. (D) RT-PCR analysis of $\beta$-catenin mRNA level in H460 tumorsphere cells treated with SNG1153. (E) Nucleocytoplasmic separation assay of the $\beta$-catenin expression in the nucleus (left) and the cytoplasm (right) in H460 tumorsphere cells treated with SNG1153. (F) Western blot analysis of the $\beta$-catenin phosphorylation and GSK-3 $\beta$ expression in H460 tumorsphere treated with SNG1153. (G) Western blot analysis of the $\beta$-catenin downstream genes (c-myc and cyclin-D1) expression in the cells treated with SNG1153. All data are representative results from three independent experiments. 1153: SNG1153. 
In this study, we demonstrated that SNG1153 inhibited growth of tumorsphere cells derived from human lung cancer H460 cells. We found that SNG1153 inhibited tumorsphere formation and self-renewal. In lung cancer, CD133 is the most useful marker for cancer stem cells, and we found that SNG1153 treatment decreased population of cells positive for CD133. Furthermore, we demonstrated that SNG1153 pretreatment reduced CSC in H460 cells and thus blocked tumor formation in vivo. Our results strongly indicated that SNG1153 can inhibit the growth of lung cancer and lung CSCs.
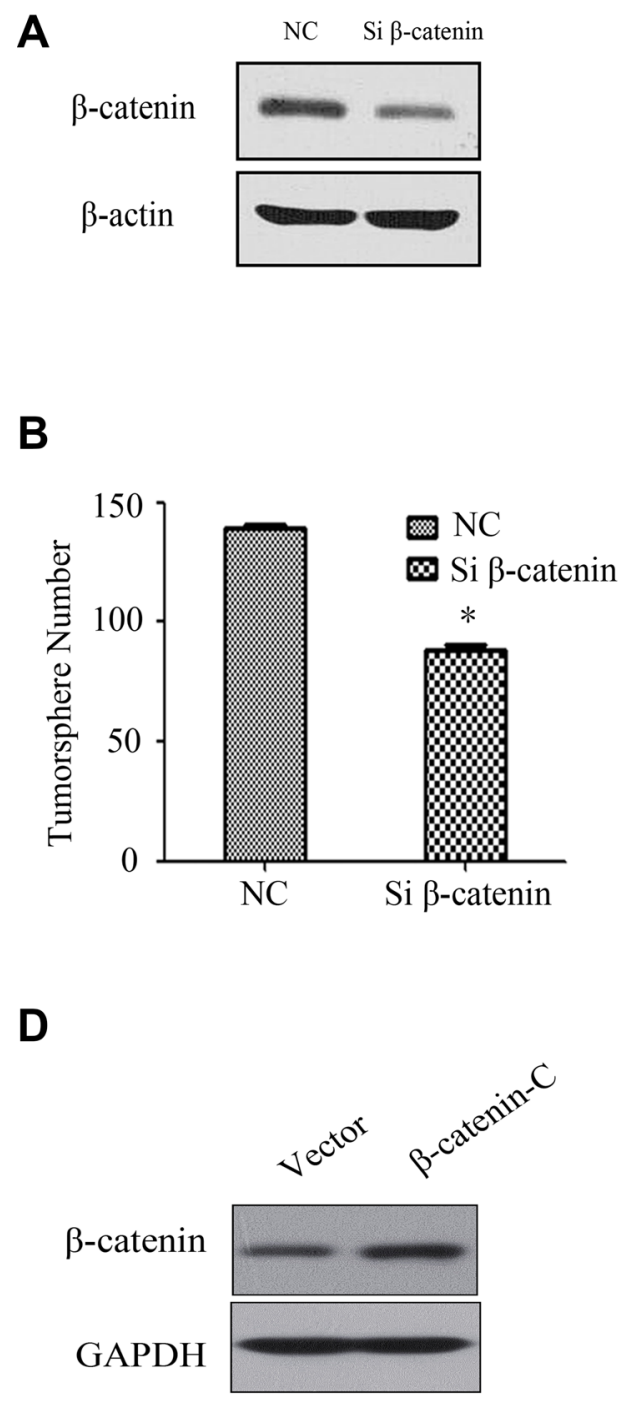

A number of studies have demonstrated that the $\mathrm{Wnt} / \beta$-catenin pathway is crucial in the maintenance of cancer stem cells in leukemia [57-59], melanoma [60], colon cancer [61] and so on. In the absence of Wnt ligands, the $\beta$-catenin is phosphorylated at residues Ser45, Thr41, Ser37, and Ser33 by a multi-protein destruction complex including GSK3 $\beta$, ubiquitinated by the E3 ligase $\beta$-TrCP and then subsequently degraded through the $26 \mathrm{~S}$ proteasome system. Wnt stimulation leads to the inhibition of $\beta$-catenin phosphorylation and degradation, and then $\beta$-catenin translocates into the nucleus where it forms a

C
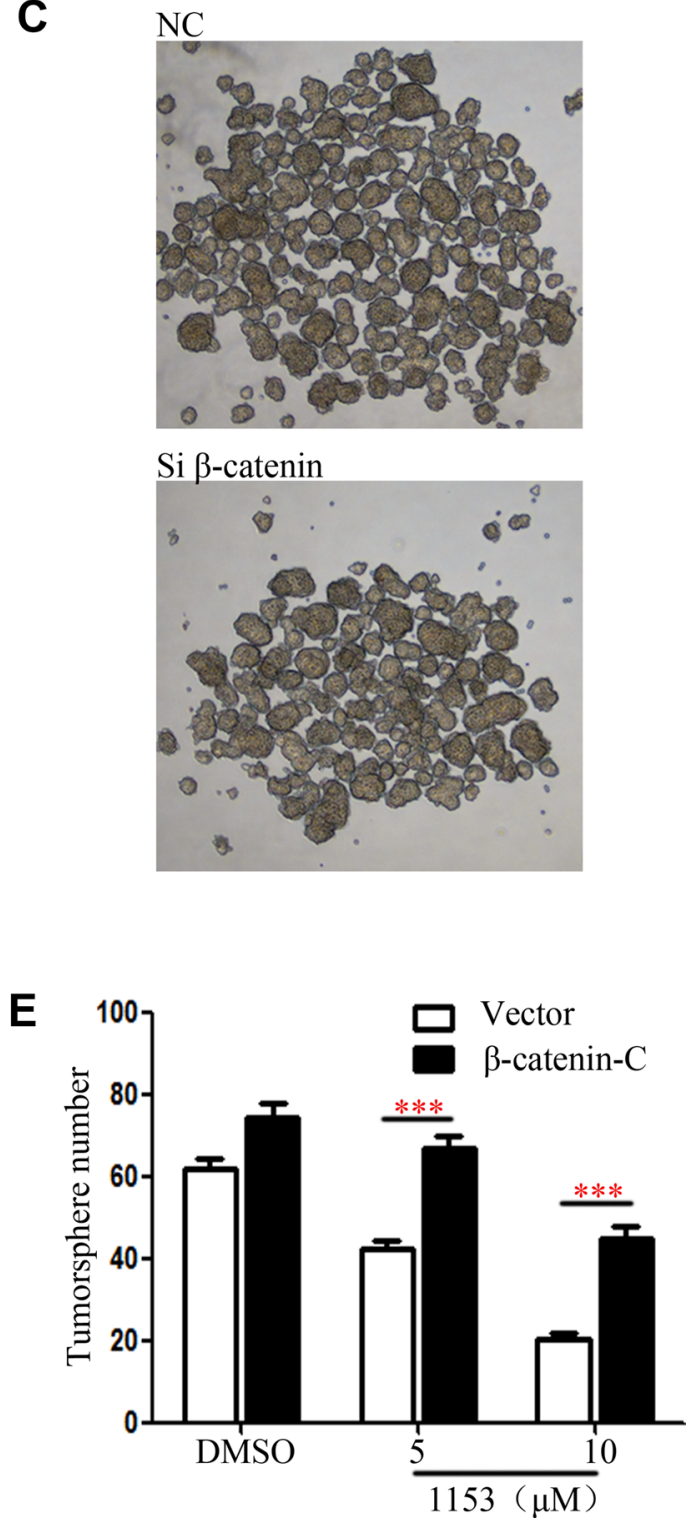

Figure 6: $\beta$-catenin Knock down attenuates tumorsphere formation and overexpression of active $\beta$-catenin weakens the SNG1153's inhibitory effect on H460 tumorspher. H460 cells transfected with the control siRNA or the $\beta$-catenin siRNA for $48 \mathrm{~h}$. (A) Total cell lysates were prepared and western blots were carried out with the indicated antibodies. (B and C) H460 were transiently transfected then cultured in tumorsphere medium for 5 days, photographed and counted. (D and E) H460 cells were transiently transfected with the vector control or the $\beta$-catenin- $\mathrm{C}(\beta$-catenin constitutive active) plasmid for $48 \mathrm{~h}$. Cells were harvested for western blots and tumorsphere formation assay. Data are representative results from three independent experiments. Points, mean $(n=3)$; bars, SEM. $* P<0.05$. 
complex with (TCF/LEF) transcription factors, activating its target genes expression, such as c-myc and cyclinD1 $[38,39]$. We found SNG1153 treatment reduced the protein levels of $\beta$-catenin, which was reversed by MG132. SNG1153 phosphorylated $\beta$-catenin and increased GSK3 $\beta$ expression. We also demonstrated SNG1153 suppresses the expression of $\beta$-catenin downstream genes, such as c-myc and cyclinD1. Lung CSC inhibition by SNG1153 is $\beta$-catenin dependent.

In this study, SNG1153 exhibited anti-growth activity in lung cancer H460 cells, and in tumorsphere cells from H460. SNG1153 inhibits lung cancer cells by down-regulating $\mathrm{Wnt} / \beta$-catenin signaling pathway. Our results provide a new piece of evidence to support our hypothesis that SNG1153 could be developed into a novel therapeutic agent for treatment of human lung cancer.

\section{MATERIALS AND METHODS}

\section{Reagents}

SNG1153 with a purity of up to $99.5 \%$ was obtained from Shenogen Pharma Group, Beijing, China. A stock solution of SNG1153 (50 mM) was prepared with DMSO (Sigma, St Louis, MO, USA). Other chemicals were purchased from Sigma unless otherwise indicated.

\section{Cell culture and cell lines}

The human lung cancer cell line H460 was obtained from the Institute of Basic Medical Sciences, Chinese Academy of Medical Sciences. Cells were maintained in RPMI-1640 medium (Gibco, USA) containing 10\% fetal bovine serum (FBS) at $37^{\circ} \mathrm{C}$ in a humidified atmosphere of $5 \% \mathrm{CO}_{2}$.

\section{CCK-8 assay}

Cell viability was measured using the CCK-8 assay kit (Dojindo), according to the manufacturer's instruction. Briefly, H460 cells were seeded in 96-well plates to a final density of $3 \times 10^{3} /$ well, and treated with vehicle (DMSO) and different concentrations of the indicated compounds for forty-eight hours. CCK-8 was then added into each well for about $1 \mathrm{~h}$, and the plates were read at wavelength of $450 \mathrm{~nm}$. Three wells were used for each treatment, and the experiments were repeated more than three times. The percentage of viable cells was calculated using the formula: ratio $(\%)=[\mathrm{OD}($ Treatment $)-\mathrm{OD}($ Blank $)] /$ [OD (Control) - OD (Blank)] × 100 .

\section{Colony formation assay}

For clonogenic assay, the cells were treated with indicated concentrations of SNG1153 or vehicle (DMSO) respectively. After $24 \mathrm{~h}$, the treated cells were suspended in $1 \mathrm{ml}$ medium containing $0.3 \%$ low-melting-point agarose (Amresco, Solon, OH, USA), and plated on a bottom layer containing $0.6 \%$ agarose in $35 \mathrm{~mm}$ plates (1000 cells/plate). After 10 days of culture, cells were stained with Giemsa and colonies containing more than 50 cells were counted and photographed.

\section{Cell apoptosis assay}

H460 cells $\left(2 \times 10^{5} /\right.$ well $)$ in six-well plates were treated with different concentrations of SNG1153 or vehicle (DMSO) respectively for $48 \mathrm{~h}$, then collected and washed twice in ice-cold PBS. Cell apoptosis assay was conducted using an AnnexinV-FITC kit (eBioscience, San Diego, CA), according to the manufacturer's instruction and the results were examined with BD LSR II ${ }^{\mathrm{TM}}$ flow cytometer (Becton-Dickinson, CA, U.S.) and analyzed with Flow Jo software (Becton-Dickinson, CA, U.S.).

\section{Tumorsphere culture}

H460 cells were suspended in serum-free DMEM/ F12 medium (Gibco) containing B27 (Invitrogen), human recombinant epidermal growth factor EGF $20 \mathrm{ng} / \mathrm{ml}$ (PeproTech), basic fibroblastic growth factor bFGF $20 \mathrm{ng} / \mathrm{ml}$ (PeproTech) and plated at 500 to $30,000 \mathrm{cell} / \mathrm{ml}$ in ultralow-attachment 24 - or 6-well plates (Corning, USA). The medium was replaced twice a week. Self-renewal capacity of the CSCs was examined by repopulating tumorspheres. Briefly, tumorspheres were collected by centrifugation, trypsinized, passed through a $45 \mathrm{~mm}$ strainer (BD, Biosciences), counted and replated in tumorsphere culture medium. Tumorspheres were defined as spheres with a diameter $>100 \mu \mathrm{m}$ size. The numbers of tumorspheres were quantitated using Image $\mathrm{J}$ software (NIH, USA).

\section{Western blot analysis}

The cells were collected and washed with ice-cold PBS and the cell extracts were prepared in RIPA buffer with proteinase inhibitor cocktail (Roche, Germany) and phosphorylation inhibitors (Sigma). Equal amounts of protein were separated by a $10 \%$ SDS-PAGE and electrotransferred to a PVDF membrane (Millipore, Temecula, CA). The membranes were then blocked, incubated with primary antibodies overnight at $4^{\circ} \mathrm{C}$, followed by incubation with the appropriate secondary antibodies. The membranes were then visualized using the enhanced chemiluminescence detection system (Engreen, China).

Monoclonal antibodies for $\beta$-catenin, $\mathrm{p}$ - $\beta$-catenin, GSK3 $\beta$, Stat3, P-Stat3 were purchased from Cell Signaling Technology. Anti-cyclinD1 antibody was from Abcam. Antibodies for c-myc, $\beta$-actin, Lamin-B, $\alpha$-tublin, GAPDH and H3 were from Santa Cruz Bio Technology (Santa Cruz, CA. USA). 


\section{FACS assay}

H460 were seeded in low attachment plates (Corning) with the concentration of 10,000 cells $/ \mathrm{ml}$. Cells were cultured for 5 days, then digested and collected. The cells were re-suspended in PBS at $2 \times 10^{6} / 100$ ul. Unstained cells, isotype and single color-stained cells were used for controls. CD133-PE antibody (Miltenyi, Biotec) was used for CD133 staining. The results were examined with $\mathrm{BD}$ AccuriTM ${ }^{\mathrm{C} 6} 6$ flow cytometer (Becton-Dickinson, CA, U.S.) and analyzed with CFlow Plus software (Becton-Dickinson, CA, U.S.).

\section{Animal experiments}

All the experimental procedures were approved by the Animal Care and Use Committee of Institute of Chinese Materia Medica, China Academy of Chinese Medical Sciences (Beijing, China). Male, 6-8 weeks old NOD/SCID mice were used (Vitalriver, Beijing, China) in mice animal experiments.

For the tumor seeding ability assay, the bulk and enriched cancer stem cells from H460 lung cancer cells were used. The cells treated with different compounds for $48 \mathrm{~h}$, and then subcutaneously injected into mice at doses of $5 \times 10^{2}$ and $5 \times 10^{4}$ per injection site. Tumor nodules usually became palpable within $2 \sim 4$ weeks after cell injection. The length and width of the tumors were measured every day. Tumor volumes were calculated as: tumor volume $=\left(\right.$ length $\times$ width $\left.^{2}\right) / 2$.

\section{Plasmids and siRNAs transfection}

Constitutively active $\beta$-catenin plasmid was from Addgene and $\beta$-catenin siRNA was from Santa Cruz Bio Technology. H460 cells $\left(2 \times 10^{5} /\right.$ well $)$ in a six-well plate were transfected with the indicated plasmids $(0.1 \mu \mathrm{g} / \mathrm{ml})$ or siRNAs $(50 \mathrm{nM})$ by Lipofectamine $3000^{\mathrm{TM}}$ following the manufacturer's instructions (Invitrogen). After $48 \mathrm{~h}$, cells were harvested for the tumorsphere formation assay or western blots.

\section{RNA extraction and reverse transcription polymerase chain reaction (RT-PCR)}

The tumorsphere were seeded at $2 \times 10^{4}$ per well in ultralow-attachment 6-well plates with tumorsphere culture medium in the presence of the indicated agents. RNA was isolated with Trizol (Invitrogen) and cDNA was synthesized according to the manufactory's instruction (AMV First Strand cDNA Synthesis Kit, NEB). RT-PCR was performed in a total reaction volume of $20 \mu$. The primers for $\beta$-catenin and $\beta$-actin were as follows: $\beta$-catenin, 5'-GAAACGGCTTTCAGTTGAGC-3' and 5'- TTCCAT CATGGGGTCCATAC-3'; $\beta$-actin, 5'-TTCCTTCCTGG GCATGGAGTCCTG -3'and 5'- GAGGAGCAATGATC TTGATCT-3'.

\section{Statistical analysis}

For reach in vitro experiment, a minimum of three wells or dishes was used and similar results were usually obtained. Each experiment was repeated at least three times. The values are represented as mean \pm SD or SEM as indicated. The difference between groups was analyzed using the Student's $t$-test when comparing only two groups or by a one-way ANOVA analysis when comparing more than two groups. Differences were considered statistically significant at $* P<0.05,{ }^{*} P P<0.01$ and $* * * P<0.001$.

\section{ACKNOWLEDGMENTS}

We thank Professor Wei Guo and Shaorong Gao for helpful comments. We also thank Yuanyuan Wang for the technical help.

\section{Abbreviations}

CSCs: cancer stem cells; RT-PCR: reverse transcription polymerase chain reaction; Stat3: Signal transducer and activator of transcription 3; Oct4: octamerbinding transcription factor 4; GSK3 $\beta$ : glycogen synthase kinase 3 beta; NOD/SCID: non-obese diabetic/severe combined immunodeficient.

\section{CONFLICTS OF INTEREST}

The authors have no conflicts to disclose.

\section{GRANT SUPPORT}

This study was supported by the China National Science and Technology Major Projects for Investigational New Drug (2013ZX09401004), Beijing Municipal Science \& Technology Commission Innovation Cultivation Projects for Biological Medicine and Bioscience (Z161100000116021), Beijing Nova Programme (No.2013073) and the Project of Changbai Mountain Scholarship of Jilin Province.

\section{REFERENCES}

1. Eramo A, Lotti F, Sette G, Pilozzi E, Biffoni M, Di Virgilio A, Conticello C, Ruco L, Peschle C, De Maria R. Identification and expansion of the tumorigenic lung cancer stem cell population. Cell Death Differ. 2008; 15:504-514.

2. Ferlay J, Shin HR, Bray F, Forman D, Mathers C, Parkin DM. Estimates of worldwide burden of cancer in 2008: GLOBOCAN 2008. Int J Cancer. 2010; 127:2893-2917.

3. Reya T, Morrison SJ, Clarke MF, Weissman IL. Stem cells, cancer, and cancer stem cells. Nature. 2001; 414:105-111.

4. Dean M, Fojo T, Bates S. Tumour stem cells and drug resistance. Nat Rev Cancer. 2005; 5:275-284. 
5. Polyak K, Haviv I, Campbell IG. Co-evolution of tumor cells and their microenvironment. Trends Genet. 2009; 25:30-38.

6. Al-Hajj M, Wicha MS, Benito-Hernandez A, Morrison SJ, Clarke MF. Prospective identification of tumorigenic breast cancer cells. Proc Natl Acad Sci U S A. 2003; 100:3983-3988.

7. Singh SK, Hawkins C, Clarke ID, Squire JA, Bayani J, Hide T, Henkelman RM, Cusimano MD, Dirks PB. Identification of human brain tumour initiating cells. Nature. 2004; 432:396-401.

8. Collins AT, Maitland NJ. Prostate cancer stem cells. Eur J Cancer. 2006; 42:1213-1218.

9. Hermann PC, Huber SL, Herrler T, Aicher A, Ellwart JW, Guba M, Bruns CJ, Heeschen C. Distinct populations of cancer stem cells determine tumor growth and metastatic activity in human pancreatic cancer. Cell Stem Cell. 2007; 1:313-323.

10. Ricci-Vitiani L, Lombardi DG, Pilozzi E, Biffoni M, Todaro M, Peschle C, De Maria R. Identification and expansion of human colon-cancer-initiating cells. Nature. 2007; 445:111-115.

11. Levina V, Marrangoni AM, DeMarco R, Gorelik E, Lokshin AE. Drug-selected human lung cancer stem cells: cytokine network, tumorigenic and metastatic properties. PLoS One. 2008; 3:e3077.

12. Dontu G, Abdallah WM, Foley JM, Jackson KW, Clarke MF, Kawamura MJ, Wicha MS. In vitro propagation and transcriptional profiling of human mammary stem/ progenitor cells. Genes Dev. 2003; 17:1253-1270.

13. Ignatova TN, Kukekov VG, Laywell ED, Suslov ON, Vrionis FD, Steindler DA. Human cortical glial tumors contain neural stem-like cells expressing astroglial and neuronal markers in vitro. Glia. 2002; 39:193-206.

14. Vescovi AL, Galli R, Reynolds BA. Brain tumour stem cells. Nat Rev Cancer. 2006; 6:425-436.

15. Miki J, Furusato B, Li H, Gu Y, Takahashi H, Egawa S, Sesterhenn IA, McLeod DG, Srivastava S, Rhim JS. Identification of putative stem cell markers, CD133 and CXCR4, in hTERT-immortalized primary nonmalignant and malignant tumor-derived human prostate epithelial cell lines and in prostate cancer specimens. Cancer Res. 2007; 67:3153-3161.

16. Anreddy N, Patel A, Zhang YK, Wang YJ, Shukla S, Kathawala RJ, Kumar P, Gupta P, Ambudkar SV, Wurpel JN, Chen ZS, Guo H. A-803467, a tetrodotoxin-resistant sodium channel blocker, modulates ABCG2-mediated MDR in vitro and in vivo. Oncotarget. 2015; 6:39276-39291. doi: 10.18632/oncotarget.5747.

17. Su YJ, Lin WH, Chang YW, Wei KC, Liang CL, Chen SC, Lee JL. Polarized cell migration induces cancer typespecific CD133/integrin/Src/Akt/GSK3beta/beta-catenin signaling required for maintenance of cancer stem cell properties. Oncotarget. 2015; 6:38029-38045. doi: 10.18632/oncotarget.5703.
18. Jones RJ, Matsui WH, Smith BD. Cancer Stem Cells: Are We Missing the Target? JNCI Journal of the National Cancer Institute. 2004; 96:583-585.

19. Liu YN, Chang TH, Tsai MF, Wu SG, Tsai TH, Chen HY, Yu SL, Yang JC, Shih JY. IL-8 confers resistance to EGFR inhibitors by inducing stem cell properties in lung cancer. Oncotarget. 2015; 6:10415-10431. doi: 10.18632/ oncotarget.3389.

20. Liu J, Xiao Z, Wong SK, Tin VP, Ho KY, Wang J, Sham MH, Wong MP. Lung cancer tumorigenicity and drug resistance are maintained through ALDH(hi)CD44(hi) tumor initiating cells. Oncotarget. 2013; 4:1698-1711. doi: 10.18632/oncotarget. 1246 .

21. Chamorro MN, Schwartz DR, Vonica A, Brivanlou AH, Cho KR, Varmus HE. FGF-20 and DKK1 are transcriptional targets of beta-catenin and FGF-20 is implicated in cancer and development. EMBO J. 2005; 24:73-84.

22. Katoh M, Katoh M. Notch ligand, JAG1, is evolutionarily conserved target of canonical WNT signaling pathway in progenitor cells. Int J Mol Med. 2006; 17:681-685.

23. Duncan AW, Rattis FM, DiMascio LN, Congdon KL, Pazianos G, Zhao C, Yoon K, Cook JM, Willert K, Gaiano N, Reya T. Integration of Notch and Wnt signaling in hematopoietic stem cell maintenance. Nat Immunol. 2005; 6:314-322.

24. Shackleton M, Vaillant F, Simpson KJ, Stingl J, Smyth GK, Asselin-Labat ML, Wu L, Lindeman GJ, Visvader JE. Generation of a functional mammary gland from a single stem cell. Nature. 2006; 439:84-88.

25. McDonald SA, Preston SL, Lovell MJ, Wright NA, Jankowski JA. Mechanisms of disease: from stem cells to colorectal cancer. Nat Clin Pract Gastroenterol Hepatol. 2006; 3:267-274.

26. van den Brink GR, Bleuming SA, Hardwick JC, Schepman BL, Offerhaus GJ, Keller JJ, Nielsen C, Gaffield W, van Deventer SJ, Roberts DJ, Peppelenbosch MP. Indian Hedgehog is an antagonist of Wnt signaling in colonic epithelial cell differentiation. Nat Genet. 2004; 36:277-282.

27. Radtke F, Clevers H, Riccio O. From gut homeostasis to cancer. Curr Mol Med. 2006; 6:275-289.

28. Hu Y, Fu L. Targeting cancer stem cells: a new therapy to cure cancer patients. Am J Cancer Res. 2012; 2:340-356.

29. Gupta PB, Onder TT, Jiang G, Tao K, Kuperwasser C, Weinberg RA, Lander ES. Identification of selective inhibitors of cancer stem cells by high-throughput screening. Cell. 2009; 138:645-659.

30. Lu D, Choi MY, Yu J, Castro JE, Kipps TJ, Carson DA. Salinomycin inhibits Wnt signaling and selectively induces apoptosis in chronic lymphocytic leukemia cells. Proc Natl Acad Sci U S A. 2011; 108:13253-13257.

31. Guo Y, Zhang X, Meng J, Wang ZY. An anticancer agent icaritin induces sustained activation of the extracellular signal-regulated kinase (ERK) pathway and inhibits growth of breast cancer cells. Eur J Pharmacol. 2011; 658:114-122. 
32. He W, Sun H, Yang B, Zhang D, Kabelitz D. Immunoregulatory effects of the herba Epimediia glycoside icariin. Arzneimittelforschung. 1995; 45:910-913.

33. Zhu J, Li Z, Zhang G, Meng K, Kuang W, Li J, Zhou X, Li R, Peng H, Dai C, Shen JK, Gong F, Xu Y, et al. Icaritin shows potent anti-leukemia activity on chronic myeloid leukemia in vitro and in vivo by regulating MAPK/ERK/ JNK, JAK2/STAT3 /AKT signalings. PLoS One. 2011; 6:e23720.

34. Wang ZQ, Lou YJ. Proliferation-stimulating effects of icaritin and desmethylicaritin in MCF-7 cells. Eur J Pharmacol. 2004; 504:147-153.

35. Zhao Y, Cui Z, Zhang L. [Effects of icariin on the differentiation of HL-60 cells]. Zhonghua Zhong Liu Za Zhi. 1997; 19:53-55.

36. Tong JS, Zhang QH, Huang X, Fu XQ, Qi ST, Wang YP, Hou Y, Sheng J, Sun QY. Icaritin Causes Sustained ERK1/2 Activation and Induces Apoptosis in Human Endometrial Cancer Cells. PLoS One. 2011; 6.

37. Zhu S, Wang Z, Li Z, Peng H, Luo Y, Deng M, Li R, Dai C, Xu Y, Liu S, Zhang G. Icaritin suppresses multiple myeloma, by inhibiting IL-6/JAK2/STAT3. Oncotarget. 2015; 6:10460-10472. doi: 10.18632/oncotarget.3399.

38. Zhao H, Guo Y, Li S, Han R, Ying J, Zhu H, Wang Y, Yin L, Han Y, Sun L, Wang Z, Lin Q, Bi X, et al. A novel anticancer agent Icaritin suppresses hepatocellular carcinoma initiation and malignant growth through the IL-6/Jak2/Stat3 pathway. Oncotarget. 2015; 6:31927-31943. doi: 10.18632/ oncotarget.5578.

39. Eyler CE, Rich JN. Survival of the fittest: cancer stem cells in therapeutic resistance and angiogenesis. J Clin Oncol. 2008; 26:2839-2845.

40. Li X, Lewis MT, Huang J, Gutierrez C, Osborne CK, Wu MF, Hilsenbeck SG, Pavlick A, Zhang X, Chamness GC, Wong H, Rosen J, Chang JC. Intrinsic resistance of tumorigenic breast cancer cells to chemotherapy. J Natl Cancer Inst. 2008; 100:672-679.

41. Lee SO, Yang X, Duan S, Tsai Y, Strojny LR, Keng P, Chen Y. IL-6 promotes growth and epithelial-mesenchymal transition of CD133+ cells of non-small cell lung cancer. Oncotarget. 2016; 7:6626-6638. doi: 10.18632/ oncotarget.6570.

42. Yi H, Cho HJ, Cho SM, Jo K, Park JA, Kim NH, Amidon GL, Kim JS, Shin HC. Blockade of interleukin-6 receptor suppresses the proliferation of $\mathrm{H} 460$ lung cancer stem cells. Int J Oncol. 2012; 41:310-316.

43. Larzabal L, El-Nikhely N, Redrado M, Seeger W, Savai R, Calvo A. Differential effects of drugs targeting cancer stem cell (CSC) and non-CSC populations on lung primary tumors and metastasis. PLoS One. 2013; 8:e79798.

44. Chiou SH, Wang ML, Chou YT, Chen CJ, Hong CF, Hsieh WJ, Chang HT, Chen YS, Lin TW, Hsu HS, Wu CW. Coexpression of Oct4 and Nanog enhances malignancy in lung adenocarcinoma by inducing cancer stem cell-like properties and epithelial-mesenchymal transdifferentiation. Cancer Res. 2010; 70:10433-10444.

45. Teng $\mathrm{Y}$, Wang X, Wang Y, Ma D. Wnt/beta-catenin signaling regulates cancer stem cells in lung cancer A549 cells. Biochem Biophys Res Commun. 2010; 392:373-379.

46. Oh S, Gwak J, Park S, Yang CS. Green tea polyphenol EGCG suppresses Wnt/beta-catenin signaling by promoting GSK3beta- and PP2A-independent beta-catenin phosphorylation/ degradation. Biofactors. 2014; 40:586-595.

47. Lippman ME. High-dose chemotherapy plus autologous bone marrow transplantation for metastatic breast cancer. N Engl J Med. 2000; 342:1119-1120.

48. Williams SD, Birch R, Einhorn LH, Irwin L, Greco FA, Loehrer PJ. Treatment of disseminated germ-cell tumors with cisplatin, bleomycin, and either vinblastine or etoposide. N Engl J Med. 1987; 316:1435-1440.

49. Jokinen E, Laurila N, Koivunen P, Koivunen JP. Combining targeted drugs to overcome and prevent resistance of solid cancers with some stem-like cell features. Oncotarget. 2014; 5:9295-9307. doi: 10.18632/oncotarget.2424.

50. Lamb R, Ozsvari B, Lisanti CL, Tanowitz HB, Howell A, Martinez-Outschoorn UE, Sotgia F, Lisanti MP. Antibiotics that target mitochondria effectively eradicate cancer stem cells, across multiple tumor types: treating cancer like an infectious disease. Oncotarget. 2015; 6:4569-4584. doi: 10.18632/oncotarget.3174.

51. Hothi P, Martins TJ, Chen L, Deleyrolle L, Yoon JG, Reynolds B, Foltz G. High-throughput chemical screens identify disulfiram as an inhibitor of human glioblastoma stem cells. Oncotarget. 2012; 3:1124-1136. doi: 10.18632/ oncotarget.707.

52. Li J, Deng H, Hu M, Fang Y, Vaughn A, Cai X, Xu L, Wan W, Li Z, Chen S, Yang X, Wu S, Xiao J. Inhibition of non-small cell lung cancer (NSCLC) growth by a novel small molecular inhibitor of EGFR. Oncotarget. 2015; 6:6749-6761. doi: 10.18632/oncotarget.3155.

53. Lamb R, Harrison $H$, Smith DL, Townsend PA, Jackson T, Ozsvari B, Martinez-Outschoorn UE, Pestell RG, Howell A, Lisanti MP, Sotgia F. Targeting tumorinitiating cells: eliminating anabolic cancer stem cells with inhibitors of protein synthesis or by mimicking caloric restriction. Oncotarget. 2015; 6:4585-4601. doi: 10.18632/ oncotarget.3278.

54. Wang Z, Zhang Y, Banerjee S, Li Y, Sarkar FH. Notch-1 down-regulation by curcumin is associated with the inhibition of cell growth and the induction of apoptosis in pancreatic cancer cells. Cancer. 2006; 106:2503-2513.

55. Jaiswal AS, Marlow BP, Gupta N, Narayan S. Betacatenin-mediated transactivation and cell-cell adhesion pathways are important in curcumin (diferuylmethane)induced growth arrest and apoptosis in colon cancer cells. Oncogene. 2002; 21:8414-8427.

56. Li Y, Zhang T, Korkaya H, Liu S, Lee HF, Newman B, Yu Y, Clouthier SG, Schwartz SJ, Wicha MS, Sun D. 
Sulforaphane, a dietary component of broccoli/broccoli sprouts, inhibits breast cancer stem cells. Clin Cancer Res. 2010; 16:2580-2590.

57. Kawaguchi-Ihara N, Murohashi I, Nara N, Tohda S. Promotion of the self-renewal capacity of human acute leukemia cells by Wnt3A. Anticancer Res. 2008; 28:2701-2704.

58. Khan NI, Bradstock KF, Bendall LJ. Activation of Wnt/ beta-catenin pathway mediates growth and survival in B-cell progenitor acute lymphoblastic leukaemia. Br J Haematol. 2007; 138:338-348.

59. Ysebaert L, Chicanne G, Demur C, De Toni F, PradeHoudellier N, Ruidavets JB, Mansat-De Mas V, RigalHuguet F, Laurent G, Payrastre B, Manenti S, RacaudSultan C. Expression of beta-catenin by acute myeloid leukemia cells predicts enhanced clonogenic capacities and poor prognosis. Leukemia. 2006; 20:1211-1216.

60. Chien AJ, Moore EC, Lonsdorf AS, Kulikauskas RM, Rothberg BG, Berger AJ, Major MB, Hwang ST, Rimm DL, Moon RT. Activated Wnt/beta-catenin signaling in melanoma is associated with decreased proliferation in patient tumors and a murine melanoma model. Proc Natl Acad Sci U S A. 2009; 106:1193-1198.

61. Vermeulen L, De Sousa EMF, van der Heijden M, Cameron K, de Jong JH, Borovski T, Tuynman JB, Todaro M, Merz C, Rodermond H, Sprick MR, Kemper K, Richel DJ, et al. Wnt activity defines colon cancer stem cells and is regulated by the microenvironment. Nat Cell Biol. 2010; 12:468-476. 